\title{
PENETAPAN KADAR STEVIOSIDA PADA SIMPLISIA DAN EKSTRAK DAUN Stevia rebaudiana DARI TIGA DAERAH BERBEDA
}

\footnotetext{
${ }^{* 1)}$ Akademi Farmasi Yarsi Pontianak

${ }^{2)}$ Fakultas Farmasi Universitas Ahmad Dahlan

${ }^{3)}$ Fakultas Farmasi Universitas Gadjah Mada

Email: diankartikasari223@gmail.com
}

\section{INTISARI}

Bahan baku obat dari hasil pertanian atau kumpulan tumbuhan liar kandungan kimianya tidak dapat dijamin selalu konstan karena adanya variabel bibit, tempat tubuh, iklim, kondisi (umur dan cara panen). Kandungan senyawa kimia yang bertanggung jawab terhadap respon biologis harus mempunyai spesifikasi kimia, yaitu informasi komposisi (jenis dan kadar). Khasiat obat tradisional berdasarkan senyawa kimia yang terkandung. Oleh karena itu penetapan kadar zat aktif suatu simplisia dan ekstrak perlu dilakukan guna menjamin bahwa suatu produk obat tradisional dapat terjamin mutu dan khasiatnya. Penetapan kadar dilakukan terhadap simplisia dan ekstrak etanol 50\% daun Stevia rebaudiana. Penetapan kadar terhadap simplisia dan ekstrak daun stevia dari daerah Malang, Tawangmangu, dan Bogor menggunakan metode High Performance Liquid Chromatograph. Hasil penetapan kadar steviosida pada simplisia dan ekstrak daun stevia diperoleh kadar steviosida pada simplisia daun stevia dari Malang, Bogor, Tawangmangu berturutturut yaitu 5,65\%; 3,89\%; 1,59\%. Kadar steviosida pada ekstrak daun stevia dari Malang, Bogor, Tawangmangu berturut-turut yaitu $14,14 \% ; 22,40 \% ; 66,65 \%$.

Kata kunci: Daun Stevia Rebaudiana, kadar steviosida, High Performance Liquid Chromatograph.

\section{ABSTRACT}

Pharmaceutical raw materials from agriculture or collection of wild plant chemical content can not be guaranteed always constant due to variable seed, the body, the climate, the conditions (age and how to harvest). The content of the chemical compounds responsible for the biological response must have chemical specifications, namely the composition information (type and concentration). The efficacy of traditional medicine based on the chemical compound. Therefore, the assay of the active substance a crude drugs and extracts needs to be done to ensure that a traditional medicinal products can be assured of quality and usefulness. The assay performed on botanicals and 50\% ethanol extract of leaves of Stevia rebaudiana. The assay of the crude drugs and extracts from the stevia leaf area of Malang, Tawangmangu, and Bogor using High Performance Liquid Chromatograph method. Results of the assay stevioside on simplicia and stevia leaf extract obtained stevioside levels in simplicia stevia leaves from Malang, Bogor, Tawangmangu consecutive namely 5.65\%; 3.89\%; 1.59\%. Stevioside levels in the stevia leaf extract of Malang, Bogor, Tawangmangu respectively, are $14.14 \% ; 22.40 \% ; 66.65 \%$.

Key word: Stevia rebaudiana leaf, stevioside content, High Performance Liquid Chromatograph

Corresponding author:

Dian kartikasari

Akademi Farmasi Yarsi Pontianak

JL. Panglima A'im No. 2 Pontianak

Email: diankartikasari223@gmail.com

\section{PENDAHULUAN}

Perkembangan obat tradisional didukung oleh Peraturan Menteri Kesehatan Republik Indonesia, tentang fitofarmaka, yang berarti diperlukannya adanya pengendalian mutu simplisia yang akan digunakan untuk bahan baku obat atau sediaan galenik (Depkes, 1979). Suatu simplisia tidak dapat dikatakan bermutu jika tidak memenuhi persyaratan mutu yang tertera dalam monografi 
simplisia salah satunya kandungan kimia berupa kadar zat aktif yang berhasiat. Persyaratan mutu ini berlaku bagi simplisia dan ekstrak yang digunakan dengan tujuan pengobatan dan pemeliharaan kesehatan (Depkes, 2008).

Bahan baku yang berasal dari lahan pertanian maupun dari tumbuhan liar kandungan bahan kimianya tidak dapat dijamin selalu konstan karena adanya berbagai variabel yang dapat mempengaruhi jumlah dan kandungan bahan kimia dari tumbuhan tersebut. Penyediaan bahan baku obat alam semestinya harus yang aman, berkhasiat, dan teruji secara ilmiah.

Stevia Rebaudiana adalah suatu sumber bahan pemanis alami yang mempunyai tingkat kemanisan 200-300 kali lebih manis dari pada gula tebu (Ratnani, 2005). Beberapa penelitian menyebutkan bahwa steviosida pada daun stevia mengandung kalori yang rendah sampai dengan nol kalori, sehingga aman bagi penderita diabetes atau konsumen yang sedang melakukan diet. Berdasarkan hasil penelitian, steviosida aman dikonsumsi oleh masyarakat umum karena tidak mempunyai efek teratogenik, mutagenic atau karsinogenik (Martono, 2011). Daun stevia memiliki aktivitas antioksidan sehingga memiliki kemampuan untuk meningkatkan sistem kekebalan tubuh dan mencegah radikal bebas penyebab penyakit (Mandal, 2013). Konstituen utama dalam daun stevia adalah glikosida diterpenoid, yang berpotensi sebagai pemanis adalah steviosida, rebaudiosides dan dulcosida (Chaturvedula, 2011).

Tumbuhan yang tumbuh ditempat berbeda pastinya memiliki kandungan aktif dan unsur hara yang berbeda. Pada penelitian ini daun stevia yang digunakan berasal dari daerah Bogor, Tawangmangu, dan Malang. Diharapkan, simplisia dan ekstrak daun S. rebaudiana dari ketiga daerah tersebut dapat ditetapkan kadar steviosidanya sehingga terjamin mutu dan khasiatnya.

Oleh karena itu, penelitian ini bertujuan untuk menetapkan kadar steviosida pada simplisia dan ekstrak daun stevia dari daerah Malang, Bogor, dan Tawangmangu dengan High Performance Liquid Chromatograph. Hasil penelitian ini diharapkan dapat memberikan informasi kandungan kadar steviosida pada simplisia dan ekstrak daun stevia dari tiga daerah berbeda, sehingga dapat digunakan sebagai acuan dalam penelitian berikutnya maupun penggunaan sebagai pengobatan.

\section{METODE PENELITIAN}

\section{Alat dan Bahan}

Alat-alat yang digunakan dalam penelitian ini adalah timbangan analitik, alat-alat gelas laboratorium, evaporator, HPLC. Simplisia daun Stevia rebaudiana diambil dari daerah Tawangmangu, Bogor, dan Malang. Etanol, aquadest.

\section{Jalannya Penelitian}

\section{Pembuatan serbuk simplisia}

Penanganan pasca panen bahan simplisia yang telah bersih dikeringkan dibawah sinar matahari dengan ditutupi kain hitam dengan alas pengering terbuat dari bambu. Setelah kering simplisia diserbuk dengan menggunakan blender.

\section{Pembuatan ekstrak 50\% secara maserasi}

Ekstrak etanol daun stevia dibuat dengan metode maserasi menggunakan penyari etanol $50 \%$. Maserat diperoleh kemudian pelarutnya diuapkan dengan menggunakan rotary evaporator hingga diperoleh ektrak cair, penguapan dilanjutkan diatas waterbath pada suhu terjaga sampai diperoleh ekstrak kental.

\section{Penetapan Kadar dengan HPLC}

Penetapan kadar simplisia dan ekstrak daun stevia menggunakan HPLC dengan kondisi operasi yang digunakan yaitu, fase gerak yang digunakan air:metanol (80:20) pH 3,0; kolom yang digunakan adalah $\mathrm{C}-18$ atau oktadensil silika (ODS); dengan panjang kolom $25 \mathrm{~cm}$ dan diameter 4,6mm; temperatur percobaan $\mathrm{HPLC} 30^{\circ} \mathrm{C}$; laju alir $0,6 \mathrm{ml} / \mathrm{menit}$; volume larutan yang diinjeksikan $20 \mu \mathrm{l}$ dan panjang gelombang $210 \mathrm{~nm}$.

\section{ANALISIS DATA}

Data yang diperoleh dari hasil pengukuran kadar steviosida menggunakan HPLC dianalisis secara deskriptif dan jelas. 


\section{HASIL DAN PEMBAHASAN \\ Ekstraksi}

Sampel yang digunakan pada penelitian ini adalah daun S. rebaudiana yang diektraksi dengan menggunakan metode maserasi. Metode maserasi dipilih sebagai metode dalam mengekstraksi karena adanya sifat daun yang lunak dan mudah mengembang dalam cairan pengekstraksi. Selain itu, maserasi merupakan cara penyarian yang sederhana karena cairan penyari akan menembus dinding sel dan masuk ke dalam rongga sel yang mengandung zat aktif. Zat aktif ini akan larut dan adanya perbedaan konsentrasi antara larutan zat aktif didalam dengan diluar sel menyebabkan larutan yang terpekat keluar hingga terjadi keseimbangan konsentrasi antara larutan di dalam dengan di luar sel (Markham, 1988). Cairan penyari yang digunakan dalam proses maserasi ini adalah etanol 50\%.

\section{Organoleptik}

Pemeriksaan organoleptik bertujuan memberikan pengenalan awal simplisia dan ekstrak secara objektif berupa bentuk, warna, bau, dan rasa. Data ini juga dapat digunakan sebagai dasar untuk menguji simplisia dan ekstrak selama penyimpanan yang dapat mempengaruhi khasiatnya. Hasil pemeriksaan organoleptik dapat dilihat pada tabel 1.

Tabel I. Data Organoleptik Simplisia dan Ekstrak Daun S. rebaudiana

\begin{tabular}{ccccc}
\hline Parameter & \multirow{2}{*}{ organoleptik } & Jenis & \multicolumn{3}{c}{ Daerah pengambilan sampel } \\
\cline { 3 - 5 } Bentuk & Simplisia & Tawangmangu & Bogor & Malang \\
& Ekstrak & Kental & Serbuk & Serbuk \\
& Simplisia & Hijau kecoklatan & Kental & Kental \\
Warna & Ekstrak & Hitam & Hitam & Hijau kecoklatan \\
& Simplisia & Khas & Khas & Hitam \\
Bau & Ekstrak & Caramel & Caramel & Khas \\
& Simplisia & Manis & Manis & Caramel \\
Rasa & Ekstrak & Manis agak pahit & Manis agak pahit & Manis agak pahit \\
\hline
\end{tabular}

Dari hasil penelitian yang telah dilakukan diperoleh data sebagai berikut: simplisia daun $S$. rebaudiana yang sudah dikeringkan dan berasal dari daerah Malang, Bogor, Tawangmangu adalah berbentuk serbuk, berwarna hijau kecoklatan, berbau khas, dan berasa manis; ekstrak etanol $50 \%$ daun S. rebaudiana dari daerah Malang, Bogor, Tawangmangu (T. Mangu) adalah berbentuk kental, berwarna hitam, berbau karamel, dan berasa manis agak pahit.

\section{Penetapan Kadar Steviosida dengan HPLC}

Fase gerak yang digunakan pada penelitian ini yaitu aquadest: metanol (80:20). Fase gerak pada HPLC bertindak sebagai pelarut sangat mempengaruhi waktu retensi, sehingga pelarut yang digunakan harus benar-benar jernih dan murni. Kromatogram larutan standar steviosida dan sampel dapat dilihat pada gambar 1.

Hasil yang terlihat pada tabel II menunjukkan data absorbansi menurun dan persen inhibisi yang meningkat seiring dengan peningkatan konsentrasi. Hal ini menunjukkan bahwa terjadi reaksi antara sampel (fraksi etanol, kloroform, vitamin C)dengan DPPH pada saat proses inkubasi. Hal ini sesuai dengan hasil penelitian (Putri, 2014), bahwa terjadi pengurangan konsentrasi DPPH setelah direaksikan dengan sampel.Hasil penentuan nilai regresi linier fraksi etanol, kloroform dan vitamin $\mathrm{C}$ dapat dilihat pada gambar 1. 


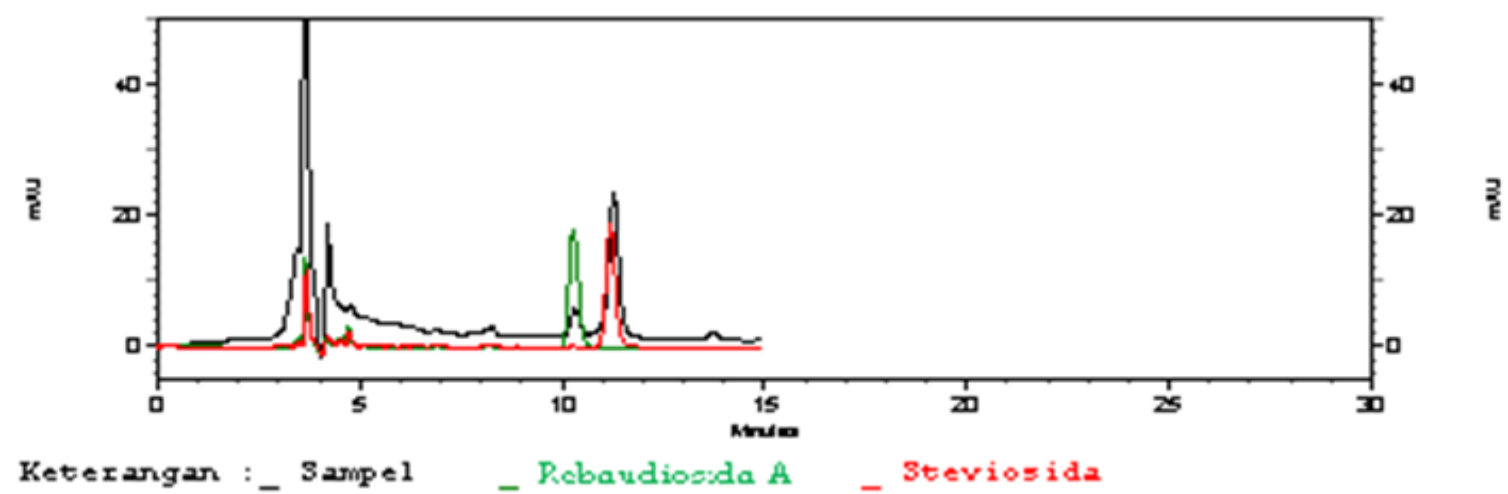

Gambar 1. Kromatogram larutan standar steviosida (warna merah) dan sampel (warna hitam). Waktu retensi steviosida 11,267 menit

Penentuan kadar steviosida secara kuantitatif memerlukan larutan standar yaitu steviosida murni. Pada data kromatogram larutan standar diperoleh waktu retensi yaitu 11,267 menit dan area sebesar 394140. Waktu retensi merupakan jangka waktu yang terukur saat sampel melewati HPLC. Larutan standar steviosida yang dibuat yaitu, $20 \mu \mathrm{g} / \mathrm{ml}, 40 \mu \mathrm{g} / \mathrm{ml}, 80 \mu \mathrm{g} / \mathrm{ml}, 100 \mu \mathrm{g} / \mathrm{ml}, 120 \mu \mathrm{g} / \mathrm{ml}$. Tabel data larutan standar steviosida yang diperoleh dapat dilihat pada Tabel II.

Tabel II. Larutan Standar Steviosida

\begin{tabular}{ccc}
\hline Konsentrasi $\boldsymbol{\mu g} / \mathbf{m l}$ & Luas area & Waktu retensi \\
\hline 20 & 67,728 & 10,683 \\
40 & 125,744 & 11,167 \\
80 & 237,311 & 11,200 \\
100 & 294,809 & 11,433 \\
120 & 359,678 & 10,717 \\
\hline
\end{tabular}

Berdasarkan tabel 2 di atas maka dibuat kurva kalibrasi, sehingga diperoleh persamaan garis y $=2,888 x+9,091$ dengan $R^{2}=0,9994$. Setelah dilakukan perhitungan menggunakan persamaan garis, maka didapat kadar steviosida pada simplisia dan ekstrak daun $S$. rebaudiana dapat dilihat pada Tabel 3 dan disajikan pada Gambar 2 dan 3.

Tabel III. Kadar steviosida pada simplisia dan ekstrak daun S.rebaudiana dari daerah Bogor, Malang dan Tawangmangu

\begin{tabular}{lc}
\hline \multicolumn{1}{c}{ Asal daerah } & Kadar $(\boldsymbol{\%} \mathbf{w} / \mathbf{w})$ \\
\hline Simplisia Malang & 5,65 \\
Simplisia Bogor & 3,89 \\
Simplisia T. Mangu & 1,59 \\
Ekstrak Malang & 14,14 \\
Ekstrak Bogor & 22,40 \\
Ekstrak T. Mangu & 66,65 \\
\hline
\end{tabular}




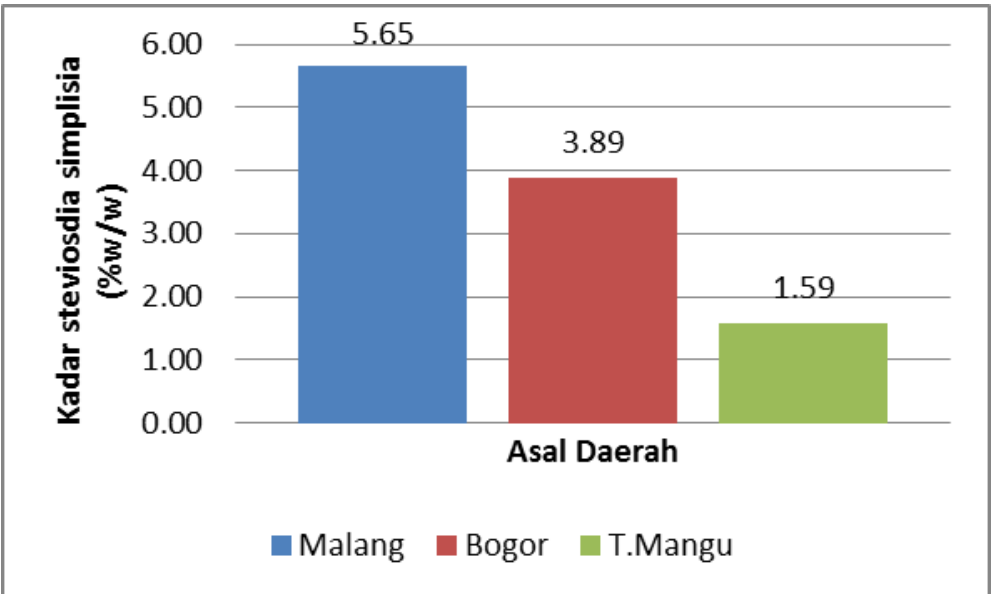

Gambar 21. Kadar steviosida pada simplisia daun S. Rebaudiana

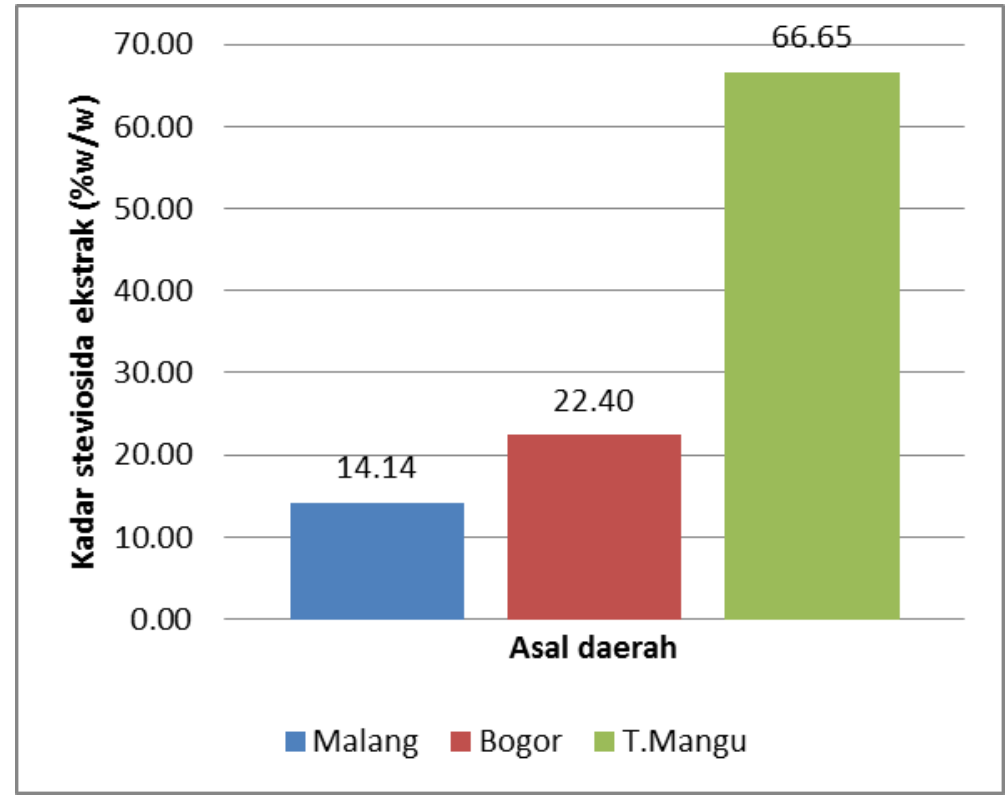

Gambar 3. Kadar steviosida pada ekstrak daun S. rebaudiana

Berdasarkan data pada tabel 2 diketahui bahwa kadar tertinggi ekstrak adalah ekstak daun $S$. rebaudiana yang berasal dari Tawangmangu yaitu $66,65 \%$, dan kadar tertinggi pada simplisia daun S. rebaudiana yang berasal dari Malang yaitu 5,65\%. Dalam hal ini terlihat bahwa kandungan steviosida dalam bentuk simplisia dari daerah Malang lebih tinggi dibanding daerah Bogor dan Tawangmangu. Hal ini kemungkinan disebabkan oleh susut pengeringan pada simplisia dari Malang jauh lebih kecil daripada simplisia dari Bogor dan Tawangmangu. Namun ketika sudah menjadi ekstrak kandungan steviosida justru lebih rendah dibanding daerah Bogor dan Tawangmangu. Hal ini kemungkinan disebabkan oleh banyaknya zat lain yang tersari sehingga kadar steviosidanya menjadi kecil. Sebaliknya kadar steviosida ekstrak dari Tawangmangu sangat jauh lebih besar. Hal ini menunjukkan bahwa ekstrak Tawangmangu dengan rendemen rendah tetapi memiliki kadar steviosida tinggi. Jika ditinjau dari sisi ekonomi akan lebih menguntungkan.

\section{KESIMPULAN}

Telah diperoleh nilai kadar steviosida dari tiga daerah pada simplisia tidak kurang dari 1,59\% dan kadar steviosida pada ekstrak tidak kurang dari 14,14\%. 


\section{DAFTAR PUSTAKA}

Chaturvedula, V., Upreti, M., \& Prakash, I. (2011). Diterpene Glycoside from Stevia Rebaudiana, Article Molecules. In O. C. The Coca Cola Company. Atlanta, USA: One Coca-Cola Plaza.

Depkes. (1979). Farmakope Indonesia Edisi III. Jakarta: Departemen Kesehatan Republik Indonesia.

Depkes. (2008). Farmakope Herbal Indonesia. Jakarta: Departemen Kesehatan Republik Indonesia.

Mandal, B., \& Madan, S. (2013). Preliminary Phytochemical Screening and Evaluation of Free Radical Scavenging Activity of Stevia Rebaudiana Bertoni from Different Geographical Source. Journal pf Pharmacognosy and Phytochemistry, IC Journal, 2(1), 14-19.

Markham, K.R., 1988, Cara Mengidentifikasi Flavonoid terjemahan, K. Radmawinata, Penerbit ITB, Bandung

Martono, Y., Dwiastuti, R., \& Sriwahyuni, A. (2011). Optimalisasi Teknik Kristalisasi Steviosida dari Stevia Rebaudiana (Bert.) sebagai Pemanis Alami Rendah Kalori. Kementrian Pendidikan Nasional. Jakarta: Direktorat Jendral Pendidikan Tinggi (Dirjen DIKTI).

Ratnani, R., \& Anggraeni, R. (2005). Ekstraksi Gula Stevia dari Tanaman Stevia Rebaudiana Bertoni,. Momentum, 1, 27-32. 